\title{
Perspektif Perlindungan Hukum Bagi Anak Dibawah Umur dalam Perkawinan Usia Muda dan Perkawinan Siri
}

\author{
Hisbah $^{1}$ \\ Fakultas Hukum Universitas Batanghari ${ }^{1}$
}

\begin{abstract}
The young generation of the son as the successor of the nation, has the right and obligation to participate in building the country. The child is the capital of development that will maintain, retain, and develop the results of development. On the other hand these children do not have the ability to complement and develop themselves, carry out rights and obligations as citizens who can afford betanggung responsible and beneficial to each other.
\end{abstract}

Keywords: legal protection, children under age, marriage series

\section{PENDAHULUAN}

Perkawinan merupakan salah satu peristiwa penting dalam kehidupan manusia. Perkawinan yang terjadi antara seorang pria dengan seorang wanita menimbulkan akibat lahir maupun batin baik terhadap keluarga masing-masing masyarakat dan juga dengan harta kekayaan yang diperoleh diantara mereka baik sebelum maupun selamanya perkawinan berlangsung. Setiap mahluk hidup memiliki hak azasi untuk melanjutkan keturunannya melalui perkawinan, yakni melalui budaya dalam melaksanakan suatu perkawinan yang dilakukan di Indonesia. Ada perbedaanperbedaannya dalam pelaksanaan yang disebabkan karena keberagaman kebudayaan atau kultur terhadap agama yang dipeluk.

Setiap orang atau pasangan (pria dengan wanita) jika sudah melakukan perkawinan maka terhadapnya ada ikatan kewajiban dan hak diantara mereka berdua dan anak-anak yang lahir dari perkawinan tersebut. Perkawinan menurut UndangUndang Nomor 1 tahun 1974 tentang Perkawinan (selanjutnya disebut UU Perkawinan) bukan hanya merupakan suatu perbuatan perdata saja, akan tetapi juga merupakan suatu perbuatan keagamaan, karena sah atau tidaknya suatuperkawinan tolak ukurnya sepenuhnya ada pada hukum masing- masing agama dan kepercayaan yang dianutnya. ${ }^{1}$

Kondisi fisik, mental, dan sosial anak yang seperti ini yang seringkali dimanfaatkan oleh pihak-pihak tertentu untuk mengambil keuntungan, hak anakanak dapat disalah-gunakan oleh pihakpihak tersebut untuk kepentingan pribadi mereka masing-masing. Anak juga merupakan pribadi sosial yang memerlukan relasi dan komunikasi dengan orang lain untuk memanusiakan dirinya. Anak ingin dicintai, ingin diakui dan dihargai. Berkeinginan pula untuk dihitung dan mendapatkan tempat dalam kelompoknya. Hanya dalam komunikasi dan relasi dengan orang lain (guru, pendidik, pengasuh, orang tua, anggota keluarga, kawan sebaya, kelompoknya dan lain-lain) seorang anak dapat berkembang menuju pada kedewasaan. ${ }^{2}$

Apabila hal itu terjadi maka akan merusak mental dan kepribadian dari si anak sekaligus berdampak negatif terhadap pelaksanaan pembangunan yang sedang berjalan. Dalam Undang-Undang Dasar Negara Republik Indonesia Tahun 1945 BAB XA Pasal 28B ayat (2) Tambahan Lembaran Negara Republik Indonesia

1 Abdurrahman, Masalah-masalah Hukum Perkawinan Di Indonesia, Penerbit Alumni, Bandung, 1978, hal. 9

${ }^{2}$ Kartini Kartono, Psikologi Anak (Psikologi Perkembangan), Mandar Maju, Bandung: 1999, hal.43 
Nomor 4316 (selanjutnya disebut UndangUndang Dasar 1945) mengatur bahwa setiap anak berhak atas kelangsungan hidup, tumbuh, dan berkembang serta berhak atas perlindungan dari kekerasan dan diskriminasi.

Dalam Undang-Undang Nomor 23 Tahun 2002 tentang Perlindungan Anak Lembaran Negara Republik Indonesia Tahun 2002 Nomor 109 dan Tambahan lembaran Negara nomor 3143 dalam BAB I mengenai Ketentuan Umum pada Pasal 1 (selanjutnya disebut Undang-Undang tentang Perlindungan Anak) mengatur bahwa anak adalah seseorang yang belum berusia 18 (delapan belas) tahun, termasuk anak yang masih dalam kandungan.

Menurut Undang-Undang Nomor 4 Tahun 1979 tentang Kesejahteraan Anak Lembaran Negara Republik Indonesia Tahun 1979 Nomor 32 dalam BAB I mengenai Ketentuan Umum pada Pasal 1 (selanjutnya disebut Undang-Undang tentang kesejahteraan Anak) Anak ialah seseorang yang belum mencapai umur 21 (dua puluh satu) tahun dan belum pernah kawin sedangkan dalam Undang-Undang Nomor 1 Tahun 1974 tentang Perkawinan, Lembaran Negara Republik Indonesia Tahun 1974 Nomor 1 dalam BAB I mengenai dasar Perkawinan pada Pasal 1 (selanjutnya disebut Undang-Undang tentang perkawinan) mengatur bahwa perkawinan adalah ikatan lahir batin antara seorang wanita sebagai suami-istri dengan tujuan membentuk keluarga (rumah tangga) yang bahagia dan kekal berdasarkan KeTuhanan Yang Maha Esa.

Kemudian dalam Undang-Undang Nomor 1 Tahun 1974 tentang Perkawinan pada BAB II Pasal 7 juga disebutkan mengenai syarat-syarat perkawinan mengatur bahwa perkawinan hanya diizinkan jika pihak pria telah mencapai umur 19 (sembilan belas tahun) dan pihak wanita sudah mencapai umur 16 (enam belas) tahun. Selanjutnya dalam persyaratan umur kawin jika dihubungkan dengan Undang-Undang Nomor 23 Tahun 2002 tentang Perlindungan Anak, khususnya BAB IV mengenai kewajiban dan tanggung jawab,bagian kesatu umum, Pasal 26 ayat (1) huruf $C$ mengatur bahwa orang tua berkewajiban dan bertanggung jawab untuk mencegah adanya perkawinan anak pada usia anak-anak atau usia muda.

\section{Rumusan Masalah}

Berdasarkan latar belakang masalah, rumusan masalah dalam penulisan ini, adalah :

1. Faktor-faktor apakah yang menjadi penyebab terjadinya perkawinan usia muda dan perkawinan siri ?

2. Bagaimanakah perlindungan hukum inabstracto terhadap anak dalam perkawinan anak pada usia muda dan perkawinan siri?

3. Bagaimanakah perlindungan hukum in concrito terhadap anak dalam perkawinan anak pada usia muda dan perkawinan siri?

\section{METODE PENELITIAN}

Tipe penelitian yang digunakan dalam penulisan penelitian ini adalah penelitian hukum normatif (normative legal research), yaitu penelitian yang mengkaji rumusan masalah yang terdapat dalam penelitian ini dengan meneliti peraturan perundang-undangan yang berlaku yang berkaitan dengan rumusan masalah dalam penelitian ini dan juga pemecahan masalahnya.

\section{PEMBAHASAN}

\section{Faktor Penyebab Terjadinya Perkawinan} Usia Muda Dan Perkawinan Siri

Faktor Penyebab Terjadinya Perkawinan Usia Muda

Pernikahan anak-anak yang menikah pada usia muda tersebut lebih menonjolkan kepentingan orangtua dibanding kepentingan anak itu sendiri. Kondisi seperti ini membuat anaktidak mampu untuk mengambil keputusan sendiri. Hal ini sangat ironis karenaseharusnya anakanak dilindungi. Hal tersebut, merupakan bentuk perdagangan anak dan bisa 
mengarah kepada eksploitasi dan kekerasanekonomi.

Jika memang benar anak tersebut mengalami kekerasan seksual danekonomi, maka pelakunya bisa dijerat dengan pasal pidana dalam Undang-Undang Nomor 23 Tahun 2002 tentang Perlindungan Anak.Orang tua mengambil peran penting dalam terjadinya perkawinan anakdi bawah umur . Peranan orang tua menjadi sangat besar karena budayapatriarki di masyarakat masih kental sekali . Budaya ini menempatkan anakperempuan bawah kekuasaan orang tua dan orang tua bisa berlaku seenaknya,sehingga tidak jarang terdapat kejadian dimana justru orang tua memaksakananaknya untuk menikah walaupun sebenarnya usia mereka masih sangat dibawah umur.

Bahkan lebih menyedihkan lagi adalah sikap orang tua yangcenderung mentelantarkan anaknya karena pada dasarnya mereka kesulitanuntuk membimbing anak mereka sendiri. adapun mengenai hal-hal yang mempengaruhi, sehingga timbul perkawinan di usia mudaantara lain adalah:

1. Rendahnya tingkat pendidikan terutama bagi masyarakat yang tinggal dipedesaan.

2. Minimnya pengetahuan dan pemahaman tentang arti dan makna sebuahperkawinan.

3. Karena tekanan ekonomi yang semakin sulit berakibat timbulnya rasafrustasi, sehingga pelarianya adalah kawin.

4. Sempitnya lapangan kerja, sementara angkatan kerja semakin membludak.

5. Hamil semasa sekolah/sebelum nikah.

6. Kemauan orang tua, dengan kata lain ada unsur perjodohan.

7. Mengikuti trend yang sedang berkembang saat ini, ikut-ikutan meramaikansuasana yang menurutnya membahagiakan

\section{Faktor Penyebab Terjadinya Perkawinan Siri}

Proses nikah siri hanya dilaksanakan wajib atau rukun nikahnya saja sedangkan sunnah nikah tidak dilakukan, khususnya mengenai mengumumkan pernikahan atau yang disebut walimah/perayaan, dengan demikian orang-orang yang mengetahui pernikahan tersebut juga terbatas pada kalangan tertentu saja.

Nikah siri dalam tinjauan sosial ada dua bentuk: pertama, pernikahan yang dilangsungkan antara mempelai lelaki dan perempuan tanpa kehadiran wali dan saksisaksi, atau dihadiri wali tanpa saksi-saksi, kemudian mereka saling berwasiat untuk merahasiakan pernikahan tersebut. Jenis pernikahan ini batil (tidak sah), karena tidak memenuhi persyaratanpersyaratannya, yaitu unsur wali dan saksisaksi dan kedua, pernikahan yang berlangsung dengan rukun-rukun dan syarat-syaratnya yang lengkap, seperti ijab kabul, wali dan saksi-saksi, akan tetapi mereka itu (suami, istri, wali dan saksisaksi) satu kata untuk merahasiakan pernikahan dari pengetahuan masyarakat atau sejumlah orang.

Menurut Undang-Undang No. 23 Tahun 2006 tentang Adminstrasi Kependudukan bahwa perkawinan merupakan salah satu peristiwa penting dalam kehidupan seseorang, meliputi kelahiran, kematian, lahir mati, perkawinan, perceraian, pengakuan anak, pengesahan anak dan perubahan status kewarganegaraan. Semua peristiwa penting tersebut wajib dilaporkan dan dicatatkan untuk tertib administrasi dalam kependudukan. Undang-Undang Kependudukan dan Undang-Undang Perkawinan mewajibkan suatu perkawinan dicatatkan.

Nikah siri. Istilah nikah siri sudah lama eksis dan dari waktu ke waktu selalu menimbulkan kontroversi. Kata siri merupakan serapan dari bahasa Arab yang artinya rahasia. Nikah siri dalam penerjemahan bebasnya diartikan 'nikah di bawah tangan' atau nikah yang tidak dicatat secara resmi dan tidak dilegalisasi dengan payung hukum positif. Nikah bawah tangan, nikah agama, kawin siri atau lebih populer dengan nikah siri 
merupakan pernikahan yang dilaksanakan sesuai dengan syarat rukun nikah dalam Islam tetapi tidak dicatatkan di Kantor Urusan Agama (KUA) atau oleh Petugas Pencatat Nikah (PPN). Berdasarkan UU No. 23 Th. 2006 Tentang Adminstrasi Kependudukan, salah satu peristiwa penting yang harus didaftar/dilaporkan adalah adanya perkawinan yang dialami oleh seseorang selain peristiwa kelahiran, kematian, lahir mati, perceraian, pengakuan anak, pengesahan anak, pengangkatan anak, perubahan nama dan perubahan status kewarganegaraan.

Dinamakan siri karena dilangsungkan secara diam-diam, tertutup, rahasia atau sembunyi-sembunyi tanpa adanya publikasi. Munculnya fenomena nikah siri yang semakin marak dilakukan, dengan alasan tertentu tanpa wali perempuan, bahkan terkadang juga tanpa saksi dan tanpa sepengetahuan orang tua pihak perempuan. Pernikahan seperti ini tidak sah secara agama dan apalagi secara hukum. Istilah nikah di bawah tangan muncul setelah UU Nomor 1/1974 berlaku secara efektif yaitu tanggal 1 Oktober 1975, nikah bawah tangan pada dasarnya adalah kebalikan dari nikah yang dilakukan menurut hukum. Dan nikah menurut hukum adalah yang diatur dalam UU perkawinan. Dengan demikian nikah bawah tangan adalah nikah yang dilakukan tidak menurut hukum sehingga nikah tersebut kategori nikah liar, sehingga tidak mempunyai akibat hukum, berupa pengakuan dan perlindungan hukum. Sebagaima yang tertuang dalam UU No. 23 Tahun 2006 Tentang Adminstrasi Kependudukan bahwa perkawinan merupakan salah satu peristiwa penting dalan kehidupan seseorang. Peristiwa penting adalah kejadian yang dialami oleh seseorang meliputi kelahiran, kematian, lahir mati, perkawinan, perceraian, pengakuan anak, pengesahan anak dan perubahan status kewarganegaraan. Semua peristiwa penting tersebut wajib dilaporkan dan dicatatkan untuk tertib administrasi dalam kependudukan.
Sebagaimana diketahui bahwa nikah siri yang merupakan salah satu peristiwa penting yang tidak dicatatkan pada KUA, sedangkan KUA adalah satuan yang melaksanakan pencatatan nikah, talak, cerai dan rujuk pada tingkat kecamatan bagi penduduk yang beragama Islam. Berdasarkan UU No. 23 Th. 2006 tentang Administrasi Kependudukan juga disebutkan bahwa setiap Warga Negara Indonesia yang melahirkan wajib melaporkan dan mencatatkan kepada instansi pelaksana di tempat terjadinya kelahiran untuk memperoleh akta kelahiran sebagaimana tercantum pada BAB V Pencatatan Sipil.

Meski secara agama atau adat istiadat dianggap sah, namun pernikahan siri yang dilakukan di luar pengetahuan dan pengawasan pegawai pencatat nikah tidak memiliki kekuatan hukum dan dianggap tidak sah di mata hukum dan anak yang lahir dari pernikahan siri sulit untuk mendapatkan akta kelahiran karena lahir bukan berdasarkan perkawinan yang sah. UU Kependudukan dan UU Perkawinan sudah mewajibkan suatu perkawinan untuk dicatatkan.

Melakukan pernikahan siri yang pertama sebagian besar dilakukan bagi mereka yang memang sudah menikah sebelumnya. Kebanyakan yang melakukan adalah diawali oleh status si suami yang sudah menikah, kemudian memilih nikah siri karena akan rumit bila harus mendapatkan ijin dari istri yang sah menurut hukum. Untuk status yang sudah menikah, nikah resmi dengan perempuan lain atau lelaki lain akan sangat sulit kemudian memilih nikah siri (untuk berpoligami) karena ingin mempunyai pasangan nikah lebih dari satu pada saat yang bersamaan, akhirnya si suami melakukan nikah siri karena akan rumit dan sulit bila harus mendapatkan ijin dari istri yang sah menurut hukum, terutama bagi mereka yang masih berstatus nikah resmi dengan seorang perempuan, hal ini juga di atur dalam Undang-Undang Perkawinan No. 1 tahun 1974 Bab 1 pasal 
4 ayat (1) dalam hal seorang suami akan beristri lagi maka wajib mengajukan permohonan kepada pengadilan.

\section{Perlindungan Hukum In Abstracto Bagi Anak Di Bawah Umur Dalam Perkawinan Usia Muda Dan Perkawinan Siri}

Perkawinan anak di bawah umur dapat terjadi karena orang tuamemiliki keterlibatan yang besar. Perbuatan yang dilakukan oleh orang tuadalam mengawinkan anak di bawah umur merupakan sebuah permasalahanhukum yang dalam pengaturannya terjadi pengaturan yang berbeda. Apabilakita melihat dari hukum positif di Indonesia maka sebenarnya perbuatanmengawinkan anak dibawah umur merupakan suatu perbuatan yang melanggar hukum atau dapat dikatakan illegal secara hukum. Banyak sekaliperundang - undangan yang menentang terjadinya perkawinan anak di bawahumur. Selain mencegah terjadinya perkawinan anak di bawah umur makaperundang - undangan yang ada juga memberikan perlindungan terhadapanak. Adapun perundang - undangan tersebut antara lain :

1. KUHP.

2. Undang - Undang Nomor 1 tahun 1974 tentang Perkawinan.

3. Undang - Undang Nomor 23 tahun 2002 tentang Perlindungan Anak

Sedangkan di sisi lain berlaku pula hukum agama dalam hal ini hukum Islam yang sering dijadikan tameng oleh para pihak gunamelegalkan terjadinya perkawinan dibawah umur. Perkawinan usia muda dapat dikatakan ilegal atau tidak sah karena merupakanbentuk pelanggaran terhadap hukum positif, yaitu terkhusus pelanggaranterhadap Undang - Undang Nomor 1 Tahun 1974 tentang Perkawinan.

Perbuatan mengawinkan anak dibawah umur tentu tidak terjadibegitu saja tetapi perlu juga dilakukan penelitian mengenai faktor-faktorpendorong apa saja yang menyebabkan terjadinya perkawinan anak dibawah umur. Orang tua yang dengan sengaja membiarkan dan berupayameraih keuntungan dalam sebuah perkawinan anak di bawah umur dapatdikategorikan pula sebagai tindak pidana , oleh karena itu penulis jugamencoba meniliti mengenai sudut pandang hukum pidana dalam perkaraperkawinan anak di bawah umur, bagaimana pengaturannya serta sanksipidana apa yang bisa dijatuhkan bagi orang tua yang memiliki keterlibatandalam perbuatan mengawinkan anak di bawah umur sehingga dapatdipidana untuk memberikan kepastian hukum.

Pemberian sanksi pidana terhadap orang tua yang terlibat dalamperkawinan anak di bawah umur merupakan upaya untuk mewujudkankepastian hukum di Indonesia, selain itu tentulah pengaturan mengenaiperkawinan anak dibawah umur harus kembali mengacu kepada hukumpositif yang mempunyai kedudukan hukum lebih tinggi daripada hukumlainnya yang secara tidak langsung tumbuh dan berkembang dimasyarakat.

Hal ini juga mengandung pengertian bahwa seluruh rakyatIndonesia harus tunduk pada hukum positif di negara ini.Pemidanaan terhadap para pihak yang mendukung atau turut serta dalam peristiwa perkawinan usia muda haruslah diterapkan hal ini mengingat perkawinan usia muda sendiri memiliki beberapa risiko yang antara lain adalah:

1. Kematian ibu yang melahirkan; Kematian karena melahirkan banyak dialami oleh ibu muda di bawah umur 20 tahun. Penyebab utama karena kondisi fisik ibu yang belum atau kurangmampu untuk melahirkan.

2. Kematian bayi; Bayi yang dilahirkan oleh ibu yang berusia muda, banyak yang mengalaminasib yang tidak menguntungkan. Ada yang lahir sebelum waktunya (prematur), ada yang berat badanya kurang dan ada pula yang langsung meninggal.

3. Hambatan terhadap kehamilan dan persalinan; Selain kematian ibu dan bayi, ibu yang kawin pada usia muda 
dapat pulamengalami perdarahan, kurang darah, persalinan yang lama dan sulit, bahkan kemungkinan menderita kanker pada mulut rahim di kemudianhari.

4. Persoalan ekonomi; Pasangan-pasangan yang menikah pada usia muda umumnya belum cukupmemiliki pengetahuan dan keterampilan, sehingga sukar mendapatkanpekerjaan dengan penghasilan yang memadai, penghasilan yang rendahdapat meretakkan keutuhan dan keharmonisan keluarga.

5. Persoalan kedewasaan; Kedewasaan seseorang sangat berhubungan erat dengan usianya, usiamuda (12-19 tahun) memperlihatkan keadaan jiwa yang selalu berubah.

Suatu perkawinan yang sudah dicatatkan pada kantor catatan sipil memiliki kekuatan hukum yang tetap dan pengakuan Negara atas perkawinan tersebut. Anak-anak atau keturunan yang lahir dari perkawinan tersebut akan dengan mudah mendapatkan status sebagai anak sah. Dalam hal pencatatan kelahiran dari anak sah tersebut akan memberikan kepastian hukum. Itulah kegunaannya suatu perkawinan yang dicatatkan pada kantor catatan sipil. Sebelum melakukan pencatatan perkawinan, pasangan suami istri harus melakukan perkawinan menurut hukum agama masing-masing. Pasal 2 ayat (1) dan (2) UU Perkawinan, suatu perkawinan yang sah harus melakukan perkawinan menurut hukum agama mereka masing-masing serta dicatatkan pada kantor catatan sipil.

Pencatatan tersebut akan adanya akta perkawinan yang dipegang oleh masingmasing pasangan. Tetapi jika perkawinannya belum melakukan upacara keagamaan maka tidak dapat dicatatkan hal ini sesuai dalam Pasal 2 ayat (1) dan (2)nya UU Perkawinan yang menjelaskan perkawinan secara agama dan secara Negara saling berkaitan. Suatu perkawinan yang akan dilaksanakan tidak melakukan prosesi perkawinan secara agama atau kata lain jika perkawinan tersebut tidak dilaksanakannya upacara keagamaan, maka akibat hukum dari perkawinan tersebut ialah pada Pasal 22 UU perkawinan yang mana perkawinan tersebut dapat dibatalkan karena tidak memenuhi syarat-syarat dari sahnya suatu perkawinan.

Semakin tertunda kebutuhan untuk mengawinkan anak-anak, para orang tuamenyadari bahwa persiapan yang lebih lama diperlukan untuk menjamin masadepan anak-anaknya, sekolah dulu sebelum mengawinkan mereka. Kecendrunganini terutama terjadi pada masyarakat di kota-kota besar atau di kalanganmasyarakat kelas sosial ekonomi menengah atas.Kecendrungan pada masyarakat untuk meningkatkan usia perkawinan initernyata didukung juga oleh UU yang berlaku di Repoblik Indonesia yaitu UU No.1/1974. Dengan adanya UU tersebut yang pelaksanaanya cukup ketat di lapangan,maka terbataslah kesempatan untuk menikah di bawah usia yang ditetapkan.

Terlebih lagi, pemerintah sendiri melalui program KB berusaha untuk lebihmeningkatkan lagi batas usia perkawinan ke umur 20 tahun untuk wanita, denganpertimbangan bahwa kehamilan pada wanita di bawah usia 20 tahun adalahkehamilan beresiko tinggi sehingga harus di hindari.Pihak individuindividu yang bersangkutan itu sendiri sehingga dengan kata lainada sejumlah faktor yang menyebabkan orang memilih untuk tidakmenikah sementara.

Sudah lebih dari satu dasawarsa Undang-Undang Nomor 1 tahun1974 tentang Perkawinan telah dilaksanakan secara nasional di Indonesia.Undang Undang ini telah memberikan landasan atau dasar hukum darisistem perkawinan di Indonesia. Hukum ini mencakup pihakpihak, yakniPemerintah dan aparaturnya, dan sisi lainnya adalah masyarakat Indonesia.Undang Undang Nomor 1 tahun 1974 telah menampung dengan semaksimalmungkin nilai-nilai perkawinan 
yang dihayati oleh bangsa Indonesia namun dilain pihak menampung pula unsur-unsur dan ketentuan hukum agama dankepercayaan masyarakat yang berhubungan dengan perkawinan.

Kepastian hukum dalam perkawinan sangat diperlukan, maka suatuperkawinan adalah sah bilamana dilakukan menurut hukum masing-masingagama dan kepercayaan serta dicatat menurut perundang-undangan yangberlaku sebagai prinsip legalitas. Sedangkan prinsip lain yang dianut olehUndang Undang Nomor 1 tahun 1974 tentang Perkawinan ialah asasmonogami. Pengecualian dapat terjadi bilamana dikehendaki oleh yangbersangkutan, sepanjang hukum dan agama mengizinkannya. Terdapat pula pembatasan usia kawin yakni calon mempelai pria 19 tahun dan calonmempelai wanita 16 tahun. Pembatasan ini mengandung maksud, bahwa calonsuami istri itu harus matang jiwa dan raganya untuk dapat melangsungkanperkawinan.

Usia perkawinan yang terlalu muda mengakibatkanmeningkatnya kasus perceraian karena kurangnya kesadaran untukbertanggungjawab dalam kehidupan berumah tangga bagi suami-istri.Batas usia kawin yang lebih rendah pada kenyataanya mengakibatkanlaju kelahiran yang lebih tinggi jika dibanding dengan batas usia kawin yanglebih tinggi. Pembatasan usia kawin ini mempunyai hubungan dengan masalahkependudukan. Untuk itulah, Undang Undang Nomor 1 Tahun 1974 membatasi yang sekaligus sebagai syarat dari suatu perkawinan yangdicantumkan dalam Bab II Undang Undang Nomor 1 Tahun 1974 harusdipatuhi oleh pihak pihak yang berkepentingan. Tetapi pada kenyataankehidupan sehari-hari masyarakat kurang menyadari akan pentingnyapembatasan usia kawin yang ditentukan dalam undang-undang tersebut.

Bahkan ada masyarakat yang melanggar norma-norma hukum tersebut karenaadanya kekhawatiran anak perempuannya menjadi perawan tua.
Untuk itu,maka tidak jarang pula para orang tua menempuh berbagai cara seperti kawinsiri (nikah yang dilakukan secara agama Islam, tapi tidak di catat padapencatat nikah) atau kawin paksa yang jelas-jelas melanggar Undang UndangNomor 1 Tahun 1974 tentang Perkawinan.

\section{Perlindungan Hukum In Concrito Bagi Anak Di Bawah Umur Dalam Perkawinan Usia Muda Dan Perkawinan Siri}

Batasan umur dewasa, yang selama ini menjadi satu polemic dan merupakan satu batu pijakan diberlakukannya hukum positif atas tindakan seseorang dalam ranah hukum, dan upaya dari pemerintah untuk keluar dari tata nilai adat maupun Hukum Tuhan yang bersifat mutklak ( sebagai pembanding hanya akan dibatasi pada sudut pandang hukum Islam ),tampak berbagai keganjilan sebagai berikut : bahwa batasan usia dewasa yang dalam Islam ( kebenaran Tuhan ) ditentukan melalui perpaduan antara baligh \& mumayis tanpa menentukan usia, ditantang oleh manusia yang mencoba mengungguli Allah ( kebenaran Tuhan ) untuk dijabarkan oleh manusia dengan menentukan batas umur dewasa dengan berbagai alasan dimana secara umum batas umur dewasa adalah 21 tahun dengan berbagai ketentuan lain berupa pendewasaan khusus yang bisa dimohonkan sejak seseorang berusia 16 th, dengan rincianPendewasaan berdasar KUH Perdata, seseorang dapat diberikan hak menjadi dewasa khusus untuk urusan tertentu sejak berusia 18th, maka UU Perkawinan memberikan batasan menjadi dewasa bagi perempuan hanya untuk menikah setelah berusia 16 Th. Sedangkan tanpa basa-basi undang-undang perlindungan anak menentukan bahwa usia dewasa adalah 18 tahun.

Selanjutnya baik KUH Perdata maupun Pidana menentukan Dewasa adalah bila seseorang berusia 21 tahun atau sudah berkawin ( menikah ) dan apa bila 
terjadi pemutusan perkawinan sebelum seseorang berusia 21 tahun baik karena perceraian maupun salah satu meninggal dunia status kedewasaannya tidak dicabut.

Pada prinsipnya perkawinan adalah sah apa bila dilakukan menurut hukum masing-masing agama dan kepercayaannya itu. ( UU Perkawinan Pasal 2 ayat 1 )Tidak ada sanksi apapun bagi orang tua atau wali yang menikahkan anaknya dalam usia dibawah 21 tahun asal dilaksanakan sesuai dengan hukum masing-masing agama dan kepercayaan. Bila Undang-undang perlindungan anak dengan tegas menyatakan bahwa seseorang yang belum berusia 18 tahun masih dianggap anakanak dan membutuhkan perlindungan dari orang tua dari segala bentuk pengeksploitasian anak , yang dipermasalahkan sekarang adalah apakah menikahkan anak yang belum berusia 18th merupakan satu tindakan mengeksploatasi anak ?Apakah seseorang yang memberikan izin pernikahan dibawah 18 tahun itu satu pelanggaran ? sedangkan dalam UU perkawinan dijelaskan seorang perempuan dapat melakukan perkawinan pada usia serendah-rendahnya 16 th dan laki-laki 19 th. Setelah mendapat ijin dari kedua orang tuanya.

Salah satu definisi dewasa menurut KUH Pidana/Perdata adalah sudah berusia 21 tahun atau sudah/pernah berkawin/menikah.Sedangkan menikah menurut Pasal 2 ayat 1 UU Perkawinan adalah, sah apa bila dilakukan menurut hukum masing-masing agama dan kepercayaannya itu.UU perlindungan anak berusaha untuk menjerat orang tua atau wali yang tidak mencegah terjadinya perkawinan pada usia anak-anak.Pasal 26 ayat (1) Orang tua berkewajiban dan bertanggung jawab untuk: c. mencegah terjadinya perkawinan pada usia anakanak.Itu bertentangan dengan UU Perkawinan pasal 6 ayat (1) Perkawinan didasarkan atas persetujuan kedua calon mempelai dan ayat (2) Untuk melangsungkan perkawinan seorang yang belum mencapai umur 21 (duapuluh satu) tahun harus mendapat ijin orang tua.Apa salahnya seorang tua memberi ijin anaknya untuk menikah dengan harapan diperolehnya berbagai kebaikan bagi masa depan anaknya ? oleh sebab itu hal ini amatlah erat kaitannya dengan masalah pendidikan, yang mana mengenai masalah pendidikan dalam Islam itu sudah diajarkan waktunya, bentuknya bahkan caranya yang semuanya tidak akan terhalang oleh adanya satu pernikahan.Pendidikan dalam Islam itu sejak dalam kandungan sampai liang lahat,tidak akan berhenti hanya karena adanya pernikahan.

Dalam Islam tidak perlu UU Perlindungan anak dari perilaku orang tuanya karena Islam telah mengatur kewajiban orang tua terhadap anak sudah dengan sangat jelas. Perilaku menyimpang orang tua terhadap anaknya menjadi kewajiban pemerintah untuk meluruskannya.Anak-anak terlantar akan secara langsung dilindungi oleh Negara, tindakan mengekspoitasi anak juga terlarang dalam Islam. Tidak ada salahnya bila UU Perlindungan anak tidak mencampur adukkan antara pernikahan dibawah usia 21 th. yang diijinkan orang tuanya dengan penjualan anak kerumah bordil atau sejenisnya.

Kalau ada anak terlantar, ada anak dijadikan komoditi, ada anak di eksploitir itu sama sekali tidak ada kaitannya dengan pernikahan secara Islam dalam usia yang oleh UU Perlindungan anak dianggap melanggar hukum. Menikah dalam Islam itu bukan melanggar hukum, dewasa dalam Islam itu tidak dibatasi usia akan tetapi baligh dan mumayis. Dalam tulisan sebelumnya sudah terbuktikan bahwa ukuran dewasa dengan pengertian baligh dan mumayis jauh lebih rasional, jauh lebih bisa dipertanggung jawabkan bila dibanding dengan pembatasan usia, baik itu 21 th, 19 th, 16 th dan sebagainya.

Perlindungan hukum adalah suatu perlindungan yang diberikan terhadap subyek hukum. Dalam bentuk perangkat hukum baik yang bersifat preventif yakni 
bentuk perlindungan hukum dimana kepada rakyat diberi kesempatan untuk mengajukan keberatan atau pendapatnya sebelum suatu keputusan pemerintah mendapat bentuk yang definitive maupun yang bersifat represif yakni bentuk perlindungan hukum dimana lebih ditujukan dalam penyelesian sengketa, baik yang tertulis maupun tidak tertulis.

Dengan kata lain perlindungan hukum sebagai suatu gambaran dari fungsi hukum, yaitu konsep dimana hukum dapat memberikan suatu keadilan, ketertiban, kepastian, kemanfaatan dan kedamaian. Beberapa unsur kata Perlindungan: ${ }^{3}$

1. Melindungi: menutupi supaya tidak terlihat/tampak, menjaga, memelihara, merawat, menyelamatkan.

2. Perlindungan; proses, cara, perbuatan tempat berlindung, hal (perbuatan), memperlindungi (menjadikan atau menyebabkan berlindung).

3. Pelindung: orang yang melindungi, alat untuk melindungi.

4. Terlindung: tertutup oleh sesuatu hingga tidak kelihatan.

5. Lindungan : yang dilindungi, cak tempat berlindung, cak perbuatan.

6. Memperlindungi: menjadikan atau menyebabkan berlindung.

7. Melindungkan: membuat diri terlindungi

Dalam UU Perkawinan pasal 1 menjelaskan bahwa "perkawinan ikatan lahir dan batin antara seorang pria dengan seorang wanita sebagai suami istri dengan tujuan membentuk keluarga (rumah tangga) yang bahagia Dan kekal berdasarkan Ketuhanan Yang Maha Esa". Serta dalam Pasal 2 ayat (1) dan (2) UU Perkawinan menjelaskan bahwa sahnya suatu perkawinan menurut hukum agamanya yang dianut serta dicatatkan pada kantor catatan sipil agar mendapatkan suatu kepastian hukum atau perlindungan hukum dalam suatu perkawian yang telah dilaksanakan.

\footnotetext{
${ }^{3}$ www.artikata.com/artiperlindungan.html, diakses pada tanggal 27 Maret 2014.
}

Suatu perkawinan telah dilakukan secara sah maka dengan sendirinya akan menimbulkan hak dan kewajiban antara suami-istri, orangtua ke anak. Dalam Pasal 30-34 UU Perkawinan mengatur mengenai hak dan kewajiban suami istri. Pasal 30 UU Perkawinan menjelaskan mengenai suami dan istri memikul kewajiban yang luhur untuk menegakkan rumah tangga yang menjadi sendi dasar dari susunan masyarakat. Pasal 34 UU Perkawinan menjelaskan bahwa suami wajib melindungi istrinya dan memberikan segala sesuatu keperluan hidup berumah tangga sesuai dengan kemampuannya dan dalam ayat (3)-nya jika suami dan istri melalaikan kewajibannya masing-masing dapat mengajukan gugatan kepada pengadilan.

Bilamana syarat sahnya suatu perkawinan tidak dilaksanakan secara benar adanya, tidak dilakukan sesuai hukum agama namun dicatatkan pada kantor catatan sipil, hal ini sangat merugikan salah satu pihak maupun keduanya. Suatu perkawinan yang hanya dilaksanakan pencatatan saja, perkawinan itu tidak sah, karena suatu perkawinan bersifat sakral, jadi diharuskan melakukan pencatatan seperti yang dikatakan dalam Pasal 2 ayat (2) UU Perkawinan. Jika suatu perkawinan tidak dilakukan sesuai syarat sahnya perkawinan maka Perkawinan tersebut tidak dapat perlindungan hukum. Penjelasan di atas yang sangat sering terjadi di masyarakat banyak hal-hal yang sering bertolak belakang dengan suatu peraturan perundang-undangan yang telah mengatur setiap warga negaranya termasuk dalam hal perkawinan. Maka dari itu perlunya sosialisasi kepada masyarakat agar mendapat suatu perlindungan hukum.

Pria dan wanita melakukan perkawinan mempunyai tujuan yang sangat diharapkan oleh keduanya yaitu keturunan. Dalam UU Perkawinan mengatur mengenai hak dan kewajiban orangtua terhadap anak dalam Pasal 45 sampai dengan Pasal 49, dalam Pasal 45 ayat (1) menyatakan kedua orang tua wajib 
memelihara dan mendidik anak-anak mereka sebaik-baiknya, ayat (2) kewajiban orang tua yang dimaksud dalam ayat (1) pasal ini berlaku sampai anak itu kawin atau dapat berdiri sendiri, kewajiban berlaku terus meskipun perkawinan antara kedua orangtuanya putus.

Dalam UU Perkawinan mengatur mengenai hak dan kewajiban orangtua dan hak dan kewajiban anak terhadap orangtuanya. Anak adalah seseorang yang tercipta karena adanya cinta dari kedua orangtuanya, sudah selayaknya orangtua memperhatikan tumbuh kembang anak mereka dan masa depan anak-anak yang lahir dari perkawinan tersebut. Seorang anak yang dilahirkan harus mendapatkan akta kelahiran yang menandakan jati dirinya. Namun untuk mendapatkan akta kelahiran pegawai pencatatan sipil meminta akta perkawinan dari kedua orangtuanya tujuannya untuk melihat apakah perkawinan yang telah dilakukan sah menurut hukum dan agamanya.

Perkawinan bagi anak di bawah umur pada intinya dapat diajukan upaya pembatalan perkawinan, yang diajukan atas dasar kondisi psikologis anak tersebut yang masih rentan dan belum stabil untuk membentuk mahligai rumah tangga, Menurut UU Perkawinan, pada prinsipnya perkawinan dapat dibatalkan apabila para pihak tidak memenuhi syarat-syarat untuk melangsungkan perkawinan. Hal ini diatur dalam Pasal 22 sampai Pasal 28 UU Perkawinan, sedangkan hal untuk mengajukan pembatalan perkawinan diatur didalam Pasal 23 UU Perkawinan:

1. Para keluarga dalam garis keturunan lurus ke atas dari suami atau istri.

2. Suami dan istri.

3. Pejabat yang berwenang hanya selama perkawinan belum diputuskan

4. Pejabat yang ditunjuk menurut Pasal 16 ayat (2) UU Perkawinan ini dan setiap orang yang mempunyai kepentingan hukum secara langsung terhadap perkawinan tersebut, tetapi hanya setelah perkawinan itu putus.
Pasal 24 ditegaskan bahwa "barang siapa karena perkawinan masih terikat dirinya dengan salah satu dari kedua belah pihak dan atas dasar masih adanya perkawinan dapat mengajukan pembatalan perkawinan yang baru, dengan tidak mengurangi ketentuan Pasal 3 ayat (2) dan Pasal 4 UU Perkawinan". Di dalam Pasal 25 mengatur mengenai tempat diajukannya permohonan pembatalan perkawinan ini, permohonan pembatalan perkawinan diajukan kepada pengadilan dalam daerah hukum dimana perkawinan dilangsungkan atau di tempat tinggal kedua suami istri, suami atau istri.

Dalam Pasal 26 UU Perkawinan dijelaskan bahwa pembatalan perkawinan juga dapat dilakukan oleh wali nikahnya yang mana dalam pasal 26 menjelaskan :

1. Perkawinan yang dilangsungkan di muka pegawai pencatat perkawinan yang tidak berwenang, wali nikah yang tidak sah atau yang dilangsungkan tanpa dihadiri oleh dua orang saksi dapat dimintakan pembatalannya oleh para keluarga dalam garis keturunan lurus ke atas dari suami istri, jaksa dan suami atau istri.

2. Hak untuk membatalkan oleh suami atau istri berdasarkan alasan dalam ayat (1) pasal ini gugur apabila mereka telah hidup bersama sebagai suami istri dan dapat memperlihatkan akta perkawinan yang dibuat pegawai pencatat perkawinan yang tidak berwenang dan perkawinan harus diperbaharui supaya sah.

Tetapi jika suatu perkawinan yang sudah mencapai lebih dari 6 bulan maka suatu pembatalan tidak dapat dilakukan mengingat Pasal 26 dan Pasal 27 UU Perkawinan, menyatakan bahwa jika lebih dari jangka waktu 6 bulan untuk mengajukan permohonan pembatalan para pihak tidak mengajukan gugatan pembatan maka hak untuk mengajukan gugatan gugur.

Dalam hukum Islam prosedur pembatalan perkawinan dapat dimohonkan kepada Pengadilan Agama diwilayah 
hukum tempat tinggal suami atau isteri atau tempat perkawinan dilangsungkan. Perkawinan batal dimulai setelah putusan Pengadilan yang mempunyai kekuatan hukum yang tetap dan berlaku sejak saat berlangsungnya perkawinan ketentuan ini diatur dalam Pasal 28 UU Perkawinan ayat (1) dan (2), pembatalan suatu perkawinan tidak berlaku surut terhadap anak-anak yang dilahirkan dari perkawinan tersebut.

Kontroversi mengenai pernikahan dengan anak di bawah umur kembali mengemuka seiring dengan terkuak kisah pernikahan 'kilat' Bupati Garut Aceng Fikri. Aktivis perlindungan anak Seto Mulyadi bahkan sampai melaporkan Aceng ke kepolisian atas dugaan pelanggaran UU No 23 Tahun 2002 tentang Perlindungan Anak.Cerita tentang perkawinan dengan anak di bawah umur bukan pertama kali ini terjadi. Beberapa tahun lalu, media juga memberitakan antara pria yang biasa disapa Syeh Puji yang menikahi seorang bocah. Syeh Puji bahkan harus melakoni persidangan atas pernikahannya itu.

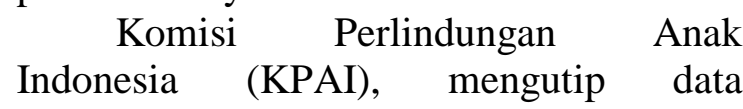
Kementerian Agama pada 2009, bahkan menyatakan bahwa sekitar 34,4 persen dari 2,5 juta perkawinan atau sekira 600 ribu pasangan yang menikah adalah mereka yang menikah di usia dini.Para aktivis perlindungan hak anak tentu tak nyaman dengan data itu. Mereka beranggapan bahwa akan banyak hak anak yang terampas ketika mereka terikat -apalagi dipaksa terikat- oleh lembaga pernikahan.

Kementerian Agama sebagai salah satu instansi yang bertanggung jawab atas urusan penyelenggaraan perkawinan sadar atas hak anak itu. Makanya kementerian telah menegaskan kepada jajarannya di tingkat Kantor Urusan Agama (KUA) untuk tidak mengizinkan perkawinan di bawah umur.

Adapun mengenai bentuk perlindungan bagi anak dalam peristiwa perkawinan usia muda dan perkawinan siri dapat dilihat dari rumusan Pasal 88
Undang-Undang Nomor 23tentang Perlindungan kemudian bentuk lebih lanjut dari perlindungan tersebut juga dapat dilihat dariPasal 290 ke-2 KUHP Jo pasal 56ke-2 KUHP. Adapun bunyi dari pasalpasal tersebut yaitu sebagai berikut :

Pasal 88 Undang-Undang Nomor 23 tahun 2002 "Setiap orang yang mengeksploitasi ekonomi atau seksual anak denganmaksud untuk menguntungkan diri sendiri atau orang lain, dipidanadengan pidana penjara paling lama 10 (sepuluh) tahun dan/atau dendapaling banyak $\mathrm{Rp}$ 200.000.000,00 (dua ratus juta rupiah).

Pasal 290 ke-2 KUHP, Barang siapa melakukan perbuatan cabul dengan seseorang, padahal iatahu atau sepatutnya harus diduganya, bahwa umur orang itu belumlima belas tahun atau kalau umurnya tidak jelas yang bersangkutanbelum waktunya dikawinkanjuncto.

Pasal 56 KUHP, Dipidana sebagai orang yang melakukan kejahatan:

1. mereka yang dengan sengaja memberi bantuan pada waktu kejahatan itu dilakukan;

2. mereka yang dengan sengaja memberi kesempatan , sarana atauketerangan untuk melakukan kejahatan itu.

Selanjutnya apabila dikaitkan dengan kasus perkawinan syekh Puji dengan ulvah maka dapat diuraiakn bahwa peristiwa tersebut telah memenuhi unsur-unsur Pasal 88 Undang-Undang Perlindungan anak, yang dapat diuraiak sebagai berikut:pembuktian dari beberapa unsur tindak pidana yang terkandung dalam Pasal88 Undang-Undang Nomor 23 tahun 2002 tentang Perlindungan Anak, yaituantara lain adalah :

1. Unsur Setiap Orang;

2. Unsur Mengeksploitasi Ekonomi atau Seksual Anak;

3. Unsur dengan Maksud Menguntungkan Diri Sendiri atau Orang Lain

Usulan pemerintah untuk mempidanakan nikah siri mengundang beragam reaksi. Kementerian Agama menyerahkan RUU Peradilan Agama tentang Perkawinan yang membahas nikah 
siri, poligami, dan kawin kontrak kepada presiden untuk diajukan ke DPR. Menurut rancangan undang-undang itu, orang-orang yang tidak melaporkan pernikahan secara hukum terancam hukuman penjara maksimal tiga bulan dan denda maksimal lima juta rupiah. Direktur Jenderal Bimbingan Masyarakat Islam Kementerian Agama Nasaruddin Umar mengatakan perubahan ini diusulkan karena akhir-akhir ini semakin banyak penyalahgunaan pernikahan siri dan mut'ah atau kawin kontrak, sehingga nasib wanita dan anakanak hasil pernikahan tersebut tidak terjamin. Dalam Islam pernikahan itu sakral dan suci, bukan hanya kontrak antara manusia dengan manusia, tetapi juga dengan Tuhan. UU Kependudukan dan UU Perkawinan sudah mewajibkan suatu perkawinan dicatatkan. Namun, kedua UU tersebut tidak mengatur sanksinya, wacana munculnya RUU peradilan Agama karena dua UU tersebut tidak mampu menekan angka perceraian dan penyelewengan.

Kementerian Agama mencatat, 48 persen dari 80 juta anak di Indonesia lahir dari proses perkawinan yang tidak tercatat, artinya, 35 juta anak di Indonesia sulit mendapatkan surat lahir, kartu tanda penduduk, hak-hak hukum seperti hak waris, dan sebagainya. Ada kecenderungan sekarang ini di kalangan masyarakat yang melakukan nikah siri atau kawin mut'ah. Begitu gampangnya mereka melakukan perkawinan, tetapi juga begitu mudahnya melakukan perceraian, meningkatnya praktek ini dalam beberapa tahun terakhir menimbulkan gelombang perceraian yang sangat tinggi, yaitu sekitar 200 ribu orang per tahun di antara 2 juta orang yang menikah, padahal sebelumnya angka perceraian rata-rata tiap tahun hanya sekitar 50.000 orang. ${ }^{4}$

Pernikahan merupakan legalisasi penyatuan antara laki-laki dan perempuan sebagai suami istri oleh institusi agama,

${ }^{4}$ Kliping.depag. go.id.diakses pada tanggal 27 Maret 2014. pemerintah atau kemasyarakatan yang memenuhi legal procedure. Salah satu jenis pernikahan yang tidak memenuhi legal procedure adalah nikah siri. Nikah siri dianggap sah oleh penduduk setempat karena sah menurut agama Islam tetapi melanggar ketentuan pemerintah. Konsepsi dan pemaknaan nikah siri tetap eksis dari waktu ke waktu dan pada dasarnya bertujuan untuk "merahasiakan" pernikahan agar ada pihak-pihak tertentu yang tidak mengetahui terjadinya pernikahan tersebut, pemaknaan nikah siri dari sisi konsep ajaran Islam, merupakan bentuk pernikahan yang secara substantif di dalamnya terdapat indikasi kekurangan syarat dan rukun perkawinan walaupun secara formal terpenuhi, sementara dari sisi terminologi sosiologis masyarakat Indonesia dalam kerangka normatif perundang-undangan perkawinan, dimaknai pada setiap pernikahan yang tidak dicatatkan oleh lembaga yang berwenang mengurusi pernikahan.

\section{SIMPULAN}

1. Faktor - faktor yang dapat mendorong terjadinya perkawinan anak dibawah umur dan perkawinan siri ternyata sangatlah kompleks dan meliputi berbagai aspek, adapun faktor - faktor tersebut adalah :

a. Faktor Ekonomi. Faktor ini merupakan faktor utama yang mendorongterjadinya perkawinan dibawah umur dan perkawinan siri dimana orangtua dapat terbebas dari tanggung jawab orang tua dan kondisi perekonomiankeluarganya dapat berubah menjadi lebih baik.

b. Faktor Kesadaran dan Pemahaman Hukum. Kurangnya kesadaran dan pemahaman hokum dari pasangan yang melakukan perkawinan usia muda dan perkawinan siri dengan tujuan tercapainya keinginan absolut tanpa menyadari akibat yang timbul dari perkawinan tersebut yaitu eksploitasi , kematian ibu melahirkan, dan terjadinya 
perceraian dimana korban adalah istri dan anak yang tidak jelas status hukumnya.

c. Faktor Kemauan. Faktor ini turut mendukung dimana kondisi psikologis seorang anak yang masih labil mempengaruhinya untuksulit menentukan mana perbuatan yang baik dan benar serta tanggung jawab dan akibat perkawinan yaitu mengenai bebantanggung jawab yang harus dipikul dalam menjalani hidup berkeluargaserta kewajibannya dalam melayani suami dan keluarganya.

2. Adapun bentuk perlindungan hukum in abstractio bagi anak dalam perkawinan usia muda perkawinan siri adalah memastikan bahwa perkawinan tersebut sah dan segera dicatatkan, dengan kata lain Perkawinan harus didahului hukum agama masing-masing karena hukum agamalah yang menentukan sah tidaknya suatu perkawinan. Setelah melakukan perkawinan dengan hukum agama, kedua mempelai di minta untuk mencatatkan pada kantor catatan sipil, gunanya mencatatkan perkawinan yang dilakukan secara administrasi agar kedua mempelai sama-sama memiliki perlindungan hukum terutama untuk wanita dan anak-anaknya tersebut.

3. Adapun bentuk perlindungan hukum inconcrito bagi anak dalam perkawinan usia muda perkawinan siri adalah memastikan bahwa ancaman pidana sebagaimana yang telah diatur dalam Undang-Undang perlindungan anak dilakasakan dengan efektif dan efisien yang harus diterapkan pada semua pihak yang mengekspoitasi anak tersebut dalam suatu ikatan perkawinan yang terlalu dini untuk dilakukan, tidak terlepas pula dari orang tua kandung anak tersebut, karena tidak menutup kemungkinan perkawinan tersebut terjadi karena desakan dan pakasaan dari orang tua kandung anak yang bersangkutan, hal ini penting untuk dilakukan demi memberikan efek jera kepada pelaku maupun para pihak yang terlibat dan bagi masyarakat supaya tidak melakukan tindakan yang sama dan bagi perkawinan usia muda untuk segera upaya pembatalan perkawinan, yang diajukan atas dasar kondisi psikologis anak tersebut yang masih rentan dan belum stabil untuk membentuk mahligai rumah tangga, Menurut UU Perkawinan, pada prinsipnya perkawinan dapat dibatalkan apabila para pihak tidak memenuhi syarat-syarat untuk melangsungkan perkawinan. Hal ini diatur dalam Pasal 22 sampai Pasal 28 UU Perkawinan.

\section{DAFTAR PUSTAKA}

\section{Buku-Buku}

Abdurrahman, Masalah-masalah Hukum Perkawinan Di Indonesia, Penerbit Alumni, Bandung, 1978

Kartini Kartono, Psikologi Anak (Psikologi Perkembangan), Mandar Maju, Bandung: 1999

Djoko Prakoso dan I Ketut Murtika, 1987, Azas-azas perkawinan di Indonesia, PT. Bina Aksara, Jakarta.

Maria Ulfah Soebadio, 1981, Perjuangan Untuk Mencapai Undang-undang Perkawinan, Idayu, Jakarta.

Taufiqurrohman Syahuri, 2013, Legislasi Hukum Perkawinan Di Indonesia, pro-kontra Pembentukannya Hingga Putusan Mahkamah Konstitusi, Kencana Prenada Media Group, Jakarta.

Wantjik Saleh. 1982 .Hukum Perkawinan Indonesia.Jakarta:Ghalia Indonesia.

Asmin, 1986, Status Perkawinan Antar Agama Ditinjau dari Undangundang Perkawinan No.1 tahun 1974, PT. Dian Rakyat, Jakarta.

Duncan J. Bioy, 1995, Family law, Head of department of law and finance University of Glamorgan.

Soedjito Tjokrowisastro, Pedoman Penyelenggaraan, Catatan Sipil, PT. Bina Aksara, Jakarta. 
ME. Rodgers, 2004, Understanding Family Law, Cavendish Publishing Limited, London.

Sudarsono, Hukum Perkawinan Nasional, Rineka Cipta, Jakarta, 2010.

Soedjito Tjokrowisastro, 1985, Pedoman Penyelenggaraan Catatan Sipil, PT. Bina Aksara, Jakarta.

Amir Syarifuddin, Hukum perkawinan Islam di Indonesia, Antara Fiqh Munakahat dan Undang-undang Perkawinan, Kencana, Jakarta, 2006.

A. Rahman I Doi, Syariah Kharakteristik Hukum Islam dan Perkawinan, GrafindoPersada, Jakarta, 1996.

Ahmad Rofiq, Hukum Islam Di Indonesia, Grafindo Persada, Jakarta, 1998.

Sayuti Thalib, Hukum Kekeluargaan Indonesia, Penerbit UI, Jakarta.

Hazairin, Tinjauan Undang-undang Perkawinan Nomor 1 Tahun 1974, Penerbit Tintamas,Jakarta, 1975.

\section{Peraturan Perundang-Undangan}

Undang-Undang Nomor 1 Tahun 1974 Tentang Perkawinan

Undang-Undang Nomor 23 Tahun 2002 tentang Perlindungan Anak

Undang-Undang Nomor 23 Tahun 2006 Tentang Administrasi Kependudukan

Undang-undang No.32 tahun 1954 tentang Pencatatan Nikah, Talak dan Rujuk

Kitab Undang-Undang Hukum Pidana

\section{PutusanPengadilan}

Putusan Mahkamah Agung RI Nomor : 1399.K/Pid/1994

Surat Tuntutan Kejaksaan Negeri Ambarawa dengan Nomor Registrasi Perkara: PDM-

63/0.3.42/EP.2/10/2009

\section{Web Site}

www.artikata.com/artiperlindungan.html, diakses pada tanggal 27 Maret 2014.

www.Kliping.depag. go.id.diakses pada tanggal 27 Maret 2014. 